L. Louze, O. Abdessemad, A.L. Nemmour, A. Khezzar

\title{
AN EFFECTIVE CONTROL OF AN ISOLATED INDUCTION GENERATOR SUPPLYING DC LOAD FOR WIND POWER CONVERTING APPLICATIONS
}

Purpose. The aim of this paper is to perform a simple and robust control method based on the well-known sliding control
approach for a self-excited induction generator supplying an isolated DC load; this adopted technique does not require much
computation and could be easily implemented in practice. In this context, the present work will begin with a mathematical
development of this control technique and its application to the self-excited induction generator case. For this purpose, the
machine provides the produced active power to the load through a static PWM converter equipped with a single capacitor on the
DC side. In order to insure the output DC-bus voltage regulation with respect to the load-power demands and the rotor speed
fluctuations, the required stator currents references are computed by considering the reactive power required for the machine
core magnetization, the induced voltages through the stator windings and the active power set value obtained from the
corresponding sliding mode DC-bus voltage controller. Regarding the nonlinearity of the DC-bus voltage mathematical model
and the discontinuity characterizing the converter-machine behavior association, the sliding mode strategy will constitute a
perfect tool to sizing the controller structure with high control performances. Results of simulation carried out to demonstrate the
proposed control validity are presented. References 26 , figures 6 . Key words: self excited induction generator, sliding mode control, DC-bus voltage regulation.

Целью данной статьи является разработка простого и надежнног метода управления, основанного на хорошо известном подходе к управлению скольжением для асинхронного генератора с самовозбуждением, питающего изолированную нагрузку постоянного тока; данный принятый метод не требует больших объемов вычислений и может быть легко реализован на практике. В этом контексте данная работа начинается с развития математических основ этого метода управления и его применения в случае асинхронного генератора с самовозбуждением. Для этого машина подает произведенную активную мощность в нагрузку через статический ШИМ-преобразователь, оснащенный единственным конденсатором на стороне постоянного тока. Чтобы обеспечить регулирование выходного напряжения шины постоянного тока с учетом требований к нагрузке и колебаниям скорости врацения ротора, требуемые токи статора рассчитываются с учетом реактивной мощцости, необходимой для намагничивания сердечника машины, наведенных напряжений в обмотках статора и заданного значения активной мощности, полученного из соответствующего контроллера напряжения шины постоянного тока в режиме скольжения. Что касается нелинейности математической модели напряжения шины постоянного тока и неоднородности, характеризующей поведение системы «преобразователь-машина», стратегия скользящего режсима будет представлять собой идеальный инструмент для определения размеров конструкции контроллера с высокими характеристиками управления. Для демонстрации обоснованности предлагаемого метода контроля, приведены результаты выполненного моделирования. Библ. 26, Рис. 6.

Ключевые слова: асинхронный генератор с самовозбуждением, управление режимом скольжения, регулирование напряжения на шине постоянного тока.

Introduction. Induction generators constitute a potential choice for off-grid applications. When operating in self-excited mode. For a given input prime movermechanical power, the squirrel-cage relative to these machines configuration requires only a reactive power to insure the main core magnetization.

Generally, the machine magnetizing procedure could be performed in several ways; from simple capacitors to complex static power conversion systems. Many studies have been presented as well as in steady-state and transient analysis of the squirrel cage induction generator based stand-alone wind energy conversion systems [1-9].

For the output-voltage self-excited induction generator (SEIG) regulation, a number of works have been proposed structures based on switched capacitors [10-15], a saturable reactors scheme [16, 17], and short shunt or long shunt configurations schemes [18-22]. Works that are more recent use voltage source converter based voltage and frequency controller [23-25].

The aim of this paper is to achieve an efficient control strategy for self-excited induction generator driven by a wind turbine and associated to a static voltage source converter with an output DC link.

For this reason, the sliding mode control strategy is applied to regulate the DC voltage on the DC side for a variable DC load taking into account the rotor speed variations. As practical uses, the regulated DC voltage obtained could be used to charge a battery set, to supply isolated DC loads or be further converted into fixedfrequency $\mathrm{AC}$ power by an inverter to supply AC loads.

Mathematical model for the self-excited induction generator. By adopting the frequently assumptions, the general equations of three-phase induction machines in the $(\alpha, \beta)$, stationary reference frame are given by:

$$
\left\{\begin{array}{l}
v_{s \alpha}=R_{s} i_{s \alpha}+L_{s} \frac{d i_{s \alpha}}{d t}+M \frac{d i_{r \alpha}}{d t} \\
v_{s \beta}=R_{s} i_{s \beta}+L_{s} \frac{d i_{s \beta}}{d t}+M \frac{d i_{r \beta}}{d t} \\
0=R_{r} i_{r \alpha}+L_{r} \frac{d i_{r \alpha}}{d t}+M \frac{d i_{s \alpha}}{d t}-\omega\left(L_{r} i_{r \beta}+M i_{s \beta}\right) \\
0=R_{r} i_{r \beta}+L_{r} \frac{d i_{r \beta}}{d t}+M \frac{d i_{s \alpha}}{d t}+\omega\left(L_{r} i_{r \alpha}+M i_{s \alpha}\right)
\end{array},\right.
$$

where $s$ and $r$ denote stator and rotor quantities; $v$ and $i$ represent instantaneous voltages and currents respectively; $R_{s}$ and $R_{r}$ are the stator and rotor resistances respectively; $L_{s}, L_{r}$ and $M$ are stator, rotor and magnetizing inductances respectively and $\omega$ represents the rotor angular velocity.

(C) L. Louze, O. Abdessemad, A.L. Nemmour, A. Khezzar 
Sliding mode control. General concepts. The general form of sliding surface which guarantees the convergence of the state $x$ to its reference $x^{*}$ is given as follows:

$$
S(x)=\left(\frac{d}{d t}+\gamma\right)^{n-1}\left(x^{*}-x\right),
$$

where $n$ is the degree of the sliding surface and $\gamma$ is a strictly positive constant.

The first convergence condition allowing the dynamic system to converge towards the sliding surfaces must verify the well-known Lyapunov function expressed in terms of the system state-variables given by:

$$
V(x)=\frac{1}{2} S^{2}(x) .
$$

To insure the Lyapunov function decreases, it is necessary to ensure that its derivative is negative. This is verified if:

$$
\dot{S}(x) S(x)<0 .
$$

In order to perform the control quantity $U_{c}$, which contains two terms, first for the exact linearization term $U_{e q}$, the second discontinuous one for the system stability $U_{n}:$

$$
U_{c}=U_{e q}+U_{n}
$$

The first control term $U_{e q}$ is obtained from the condition $\dot{S}(x)=0$ when the second control term $U_{n}$ is selected to guarantee the attractivity of the variable to be controlled towards the commutation surface.

Application to the self-excited induction generator. For the induction generator sliding mode controller design, the adopted switching surface is:

$$
S=V_{d c}^{*}-V_{d c},
$$

where $V_{d c}$ denotes the DC voltage in the DC side.

The derivative of (6) gives:

$$
\dot{S}=\dot{V}_{d c}^{*}-\dot{V}_{d c} .
$$

If the inverter losses are neglected, the relationship between the DC-bus power $P_{d c}$ and the stator power side $P_{s}$ is as follows:

$$
P_{s}=P_{d c}+P_{\text {load }},
$$

where $P_{\text {load }}$ denotes the active power consumed by the load on the DC-bus side.

Taking into account that the capacitor power $P_{d c}$ is expressed by:

$$
P_{d c}=V_{d c} i_{d c}=C V_{d c} \dot{V}_{d c},
$$

where $C$ represents the capacitor value on the converter DC side, therefore:

$$
P_{s}=C V_{d c} \dot{V}_{d c}+P_{\text {load }}
$$

From (10), the output DC bus voltage derivative is given by:

$$
\dot{V}_{d c}=\frac{1}{C V_{d c}}\left(P_{s}-P_{l o a d}\right) .
$$

From (11), (7) becomes:

$$
\dot{S}=\dot{V}_{d c}^{*}-\frac{1}{C V_{d c}}\left(P_{s}-P_{\text {load }}\right) \text {. }
$$

By referring to (11), it is clear that $P_{s}$ represents the control quantity and $P_{\text {load }}$ acts as a disturbance for the $V_{d c}$ closed control loop.

For sliding mode purposes, the control quantity set value $P_{S}^{*}$ takes the form of (5) as:

$$
P_{S}^{*}=P_{s_{-} e q}+P_{s_{-} n} .
$$

Under these conditions, (12) gives:

$$
\dot{S}=\dot{V}_{d c}^{*}-\frac{1}{C V_{d c}}\left(P_{s_{-} e q}+P_{s_{-} n}-P_{\text {load }}\right) \text {. }
$$

In the steady state conditions, the sliding surface is zero, and therefore its derivative and the discontinuous part are also zero, so:

$$
P_{s_{-} e q}=C V_{d c} \dot{V}_{d c}^{*}+P_{\text {load }} .
$$

By replacing the equivalent control with its expression in (14), the following surface derivative is obtained:

$$
\dot{S}=-\frac{1}{C V_{d c}} P_{S_{-} n} .
$$

The attractiveness condition expressed by (4) relative to the Lyapunov condition imposes the following choice of the $P_{S_{-} n}$ according to:

$$
P_{S_{-} n}=k \times \operatorname{sign}(S) \text {, }
$$

where $k$ is a positive gain.

Finally, the global control is performed by the following equation:

$$
P_{S}^{*}=C \dot{V}_{d c}^{*}+P_{\text {load }}+k \times \operatorname{sign}(S) .
$$

Since the active and reactive stator powers can be expressed in terms of the stator current components $i_{s \alpha}$ and $i_{s \beta}$ as:

$$
\left[\begin{array}{c}
P_{s}^{*} \\
Q_{s}^{*}
\end{array}\right]=\left[\begin{array}{ll}
v_{s \alpha} & v_{s \beta} \\
-v_{s \beta} & v_{s \alpha}
\end{array}\right]\left[\begin{array}{l}
i_{s \alpha}^{*} \\
i_{s \beta}^{*}
\end{array}\right] .
$$

Then, the reference stator current components $i_{s \alpha}^{*}$ and $i_{s \beta}^{*}$ to be injected to the stator windings are given by:

$$
\left[\begin{array}{c}
i_{s \alpha}^{*} \\
i_{s \beta}^{*}
\end{array}\right]=\left[\begin{array}{ll}
v_{s \alpha} & v_{s \beta} \\
-v_{s \beta} & v_{s \alpha}
\end{array}\right]^{-1}\left[\begin{array}{c}
P_{s}^{*} \\
Q_{s}^{*}
\end{array}\right] .
$$

Figure 1 shows the corresponding controller structure relative to the used sliding mode method.

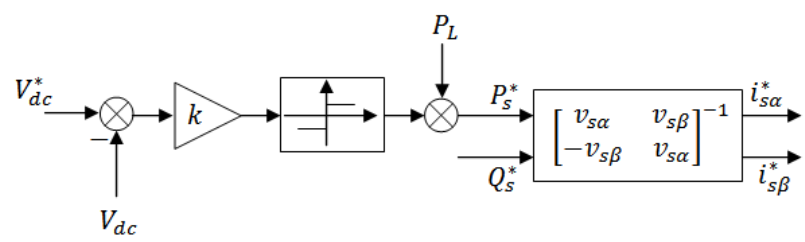

Fig. 1. Sliding mode control applied to the DC-bus voltage regulation

The proposed control scheme using hysteresis controllers is shown in Fig. 2.

Simulations and results. The proposed control has been simulated for an induction machine with the following parameters [26]: (3.6 kW, $415 \mathrm{~V}, 7.8 \mathrm{~A}, 50 \mathrm{~Hz}, 4$ poles), 
whose per-phase equivalent circuit constants are: $L_{s}=L_{r}=$ $=241.4 \mathrm{mH}, M=230 \mathrm{mH}, R_{s}=1.7 \Omega$ and $R_{r}=2.7 \Omega$.

The DC-bus voltage regulation and the corresponding main machine's characteristics obtained using the proposed sliding mode controller in presence of stern disturbances such as a step-changing of the load power $P_{\text {load }}$, a step-changing of the DC-bus voltage reference value and finally, when the wind turbine imposes to the induction generator shaft a variable speed profile.

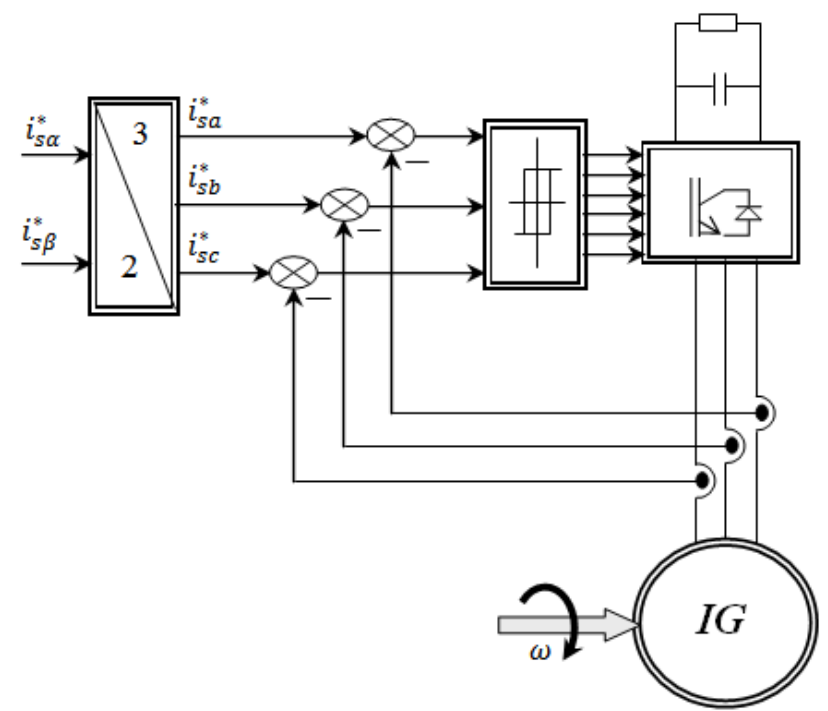

Fig. 2. Induction generator (IG) control structure used

The DC-bus voltage regulation performances under a constant rotor speed. Figure 3 shows the dynamic responses of the no-load operation followed up by a sudden load power variation $P_{\text {load }}=3500 \mathrm{~W}$ introduced at $t=0.5 \mathrm{~s}$, then a step changing of the DC-bus voltage from $600 \mathrm{~V}$ to $700 \mathrm{~V}$ introduced at $t=1 \mathrm{~s}$.
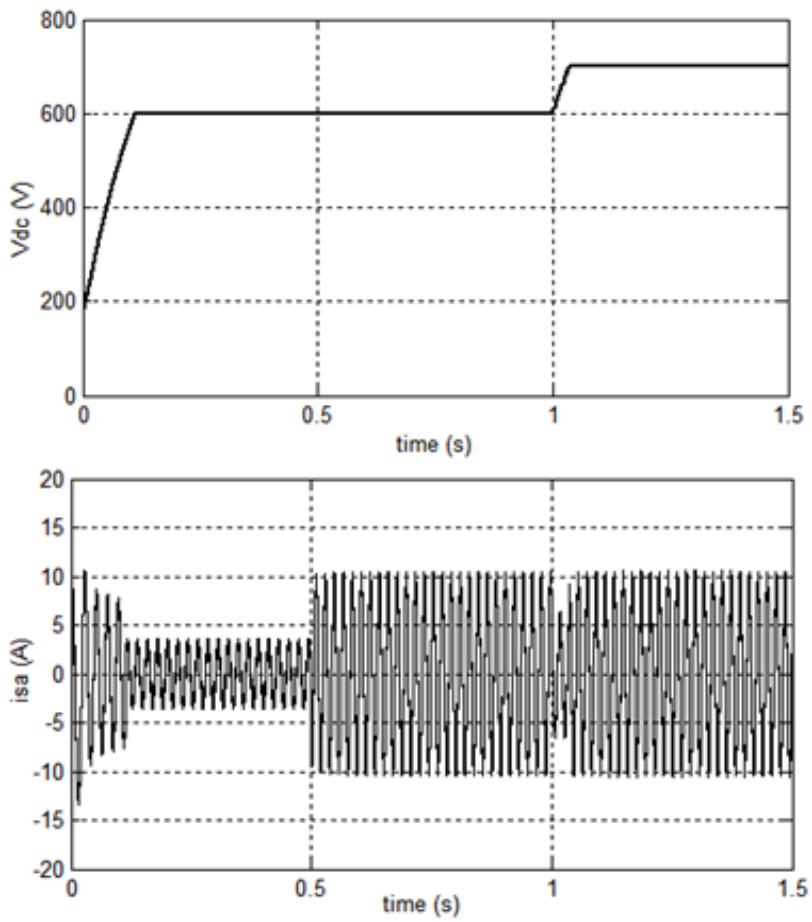

Fig. 3. The generator performances $(\omega=300 \mathrm{rad} / \mathrm{s}$ and $C=1000 \mu \mathrm{F})$
The proposed control method based on the described sliding mode controller offers a fast DC-bus voltage response and it is perfectly tracked to its set reference. In spite of a sudden power load introduction, this disturbance is instantaneously rejected and the control performances are not affected.

The speed variation effects for a given capacitor value. Figure 4 illustrates the influence of the changing speed effects on the voltage build-up process. The same load will be applied for all following sub-sections $\left(P_{\text {load }}=3500 \mathrm{~W}\right.$ at $\left.t=0.5 \mathrm{~s}\right)$. The proposed SEIG system control tracking performances is unaffected to the considered rotor speed variations.
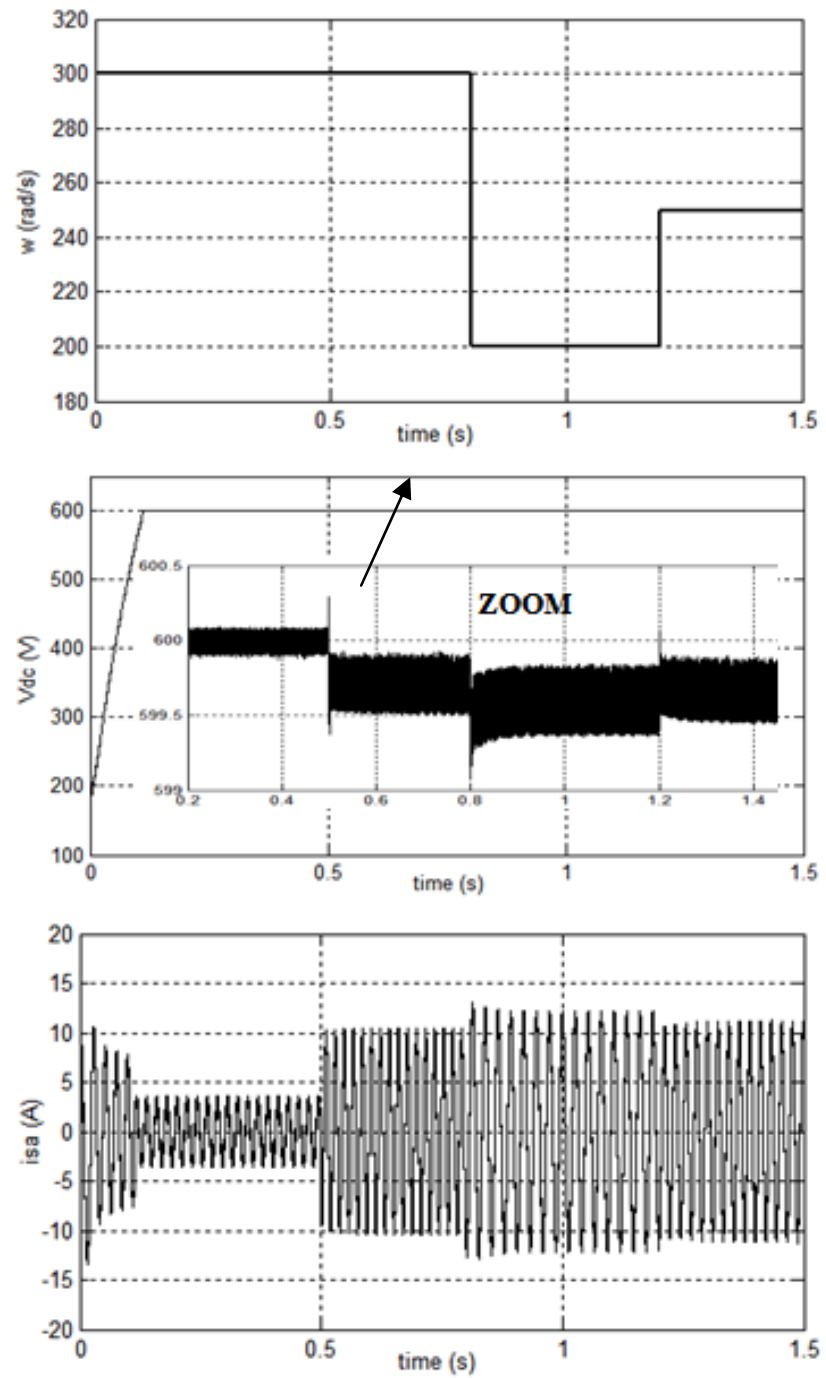

Fig. 4. The generator performances $(C=1000 \mu \mathrm{F})$

The DC-bus voltage regulation performances under a practical rotor speed profile and load power demand. In order to simulate a practical case relative to the wind profile nature that imposes to the shaft the waveform represented on Fig. 5,a. The DC load is assumed to change according to the profile of Fig. 5, $b$, when the DC-bus voltage set value is fixed at $600 \mathrm{~V}$ (Fig. 5,c). The current rate is according to the demand of the load (Fig. 5,d). 


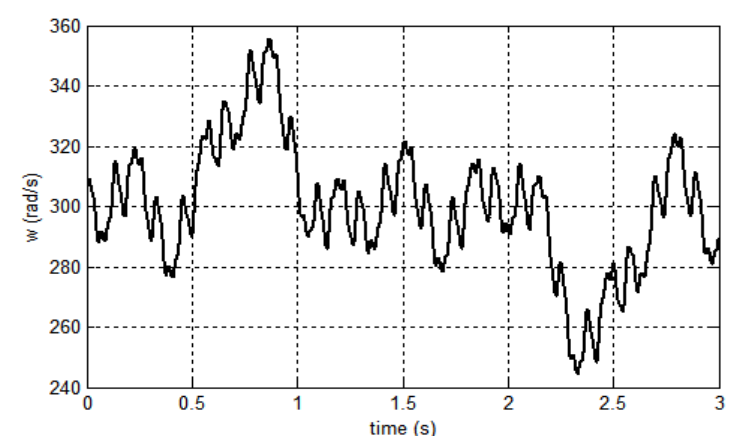

$a$

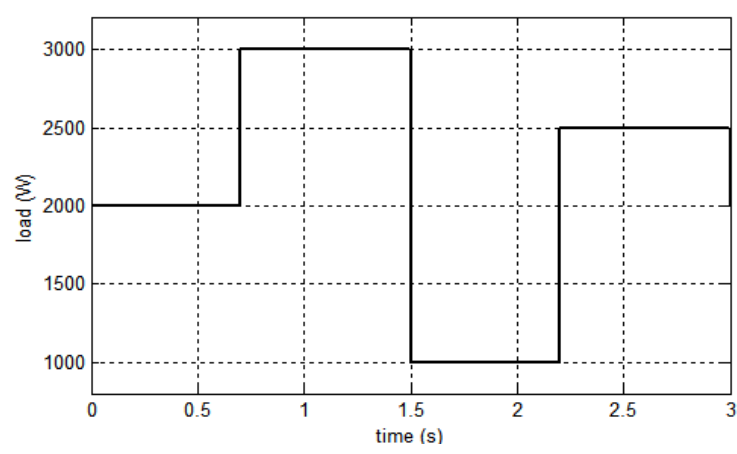

b

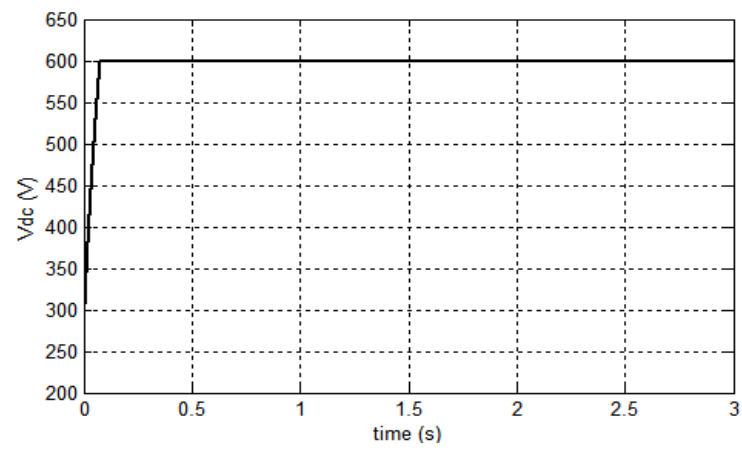

$c$

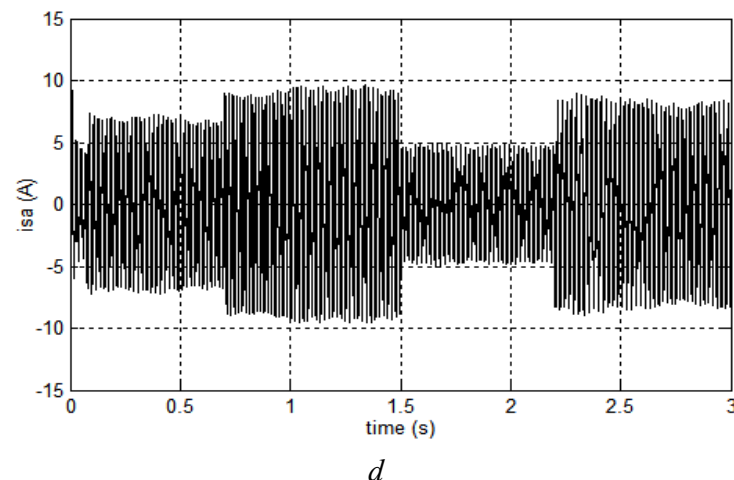

Fig. 5. The generator performances under speed and load variations

Robustness against variation in generator parameters. To verify the robustness of the proposed nonlinear control algorithm, some parameters changing is considered (case of stator rotor resistances changing). Figure 6 shows the control system performances when both stator and rotor resistances are intentionally augmented by $100 \%$ with respect to the rated values under a constant rotor speed profile. The DC-bus voltage regulation still insensitive to the considered machine parameters variations.
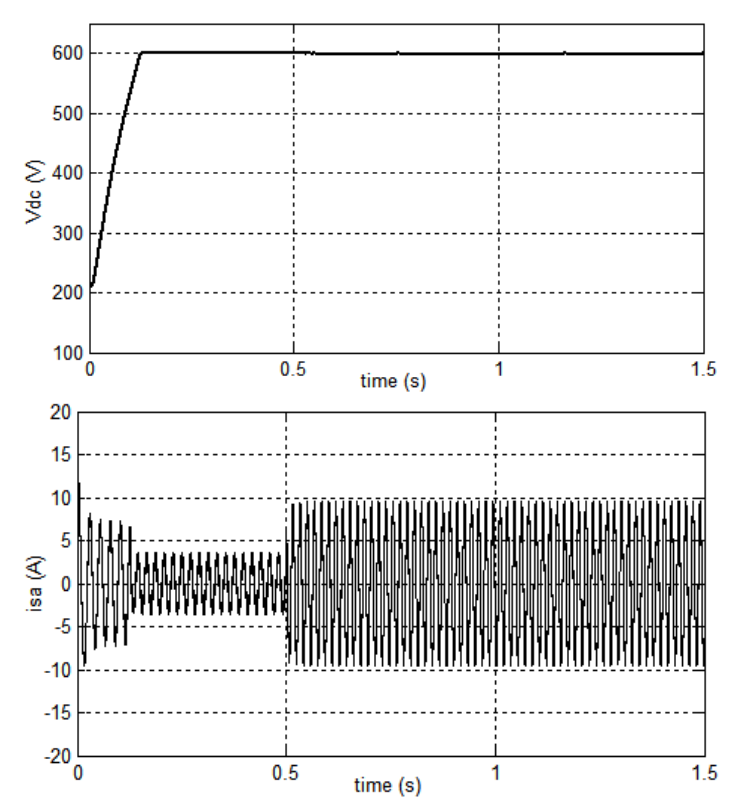

Fig. 6. The generator performances under stator and rotor resistances changing

Conclusion. This paper presents an efficient control approach based on the sliding mode theory for an induction generator operating in stand-alone mode associated to a pulse width modulation static converter with an intermediate DC link. The proposed control algorithm offers a perfect control performances under a simultaneously variation of the load power variation between $1 \mathrm{~kW}$ and $3 \mathrm{~kW}$ and the rotor speed between almost $240 \mathrm{rad} / \mathrm{s}$ and $360 \mathrm{rad} / \mathrm{s}$. Moreover, these control characteristics remain insensitive to the machine parameters derives represented by $100 \%$ of the stator and rotor resistances increase with respect to their nominal values. The obtained results show that the DC bus voltage tracking performance remains intact. The proposed system conversion control could be very useful for the wind power generating plants.

\section{REFERENCES}

1. AI Jabri A.K., Alolah A.I. Capacitance requirement for isolated self-excited induction generator. IEE Proceedings $B$ Electric Power Applications, 1990, vol. 137, no. 3, pp. 154-159. doi: 10.1049/ip-b.1990.0016.

2. Chan T.F. Capacitance requirements of self-excited induction generators. IEEE Transactions on Energy Conversion, 1993, vol. 8, no. 2, pp. 304-311. doi: 10.1109/60.222721.

3. Harrington R.J., Bassiouny F.M.M. New approach to determine the critical capacitance for self-excited induction generators. IEEE Transactions on Energy Conversion, 1998, vol. 13, no. 3, pp. 244-249. doi: 10.1109/60.707603.

4. Seyoum D., Rahman M.F. The dynamic characteristics of an isolated self-excited induction generator driven by a wind turbine. Industry Applications Society Annual Meeting (IAS), Conference Record of the IEEE. doi: 10.1109/IAS.2002.1042641.

5. Sandhu K.S., Jain S.P. Steady state operation of self-excited induction generator with varying wind speeds. International Journal of Circuits, Systems and Signal Processing, 2008, vol. 2, no. 1, pp. 26-33.

6. Haque M.H. A novel method of evaluating performance characteristics of a self-excited induction generator. IEEE Transactions on Energy Conversion, 2009, vol. 24, no. 2, pp. 358-365. doi: 10.1109/TEC.2009.2016124. 
7. Bhim S., Madhusudan S., Tandon A.K. Transient performance of series-compensated three-phase self-excited induction generator feeding dynamic loads. IEEE Transactions on Industry Applications, 2010, vol. 46, no. 4, pp. 1271-1280. doi: 10.1109/TIA.2010.2049556.

8. Kheldoun A., Refoufi L., Khodja D.E. Analysis of the selfexcited induction generator steady state performance using a new efficient algorithm. Electric Power Systems Research, 2012, vol. 86, no. 2, pp. 61-67. doi: 10.1016/j.epsr.2011.12.003. 9. Haitao L., Lili C., Xiaodan Z., Yunxia L., Xuehu P. Buildup steady-state analysis of wind-driven self-excited induction generators. The Journal of Engineering, 2017, vol. 2017, no. 13, pp. 1383-1387. doi: 10.1049/joe.2017.0558.

10. Elsharkawi M.A., Venkata S.S., Williams T.J., Butlar N.G. an adaptive power factor controller for three-phase induction generators. IEEE Transactions on Power Apparatus and Systems, 1985, vol. PAS-104, no. 7, pp. 1825-1831. doi: 10.1109/TPAS.1985.319219.

11. Malik N.H., Al-Bahrani A.H. Influence of the terminal capacitor on the performance characteristics of a self-excited induction generator. IEE Proceedings $C$ Generation, Transmission and Distribution, 1990, vol. 137, no. 2, pp. 168173. doi: 10.1049/ip-c.1990.0022.

12. Wang L., Dong-Jing L. Coordination Control of an AC-toDC Converter and a Switched Excitation Capacitor Bank for an Autonomous Self-Excited Induction Generator in RenewableEnergy Systems. IEEE Transactions on Industry Applications, 2014, vol. 50, no. 4, pp. 2828-2836. doi: 10.1109/TIA.2014.2298555.

13. Stuty K., Bhuvaneswari G. Voltage regulation of a standalone Three-phase SEIG feeding single-phase loads. IEEE Students' Conference on Electrical, Electronics and Computer Science, 2014, doi: 10.1109/SCEECS.2014.6804472.

14. Mazurenko L.I., Dzhura O.V., Shevchuk S.P. Transients in a transistor-switched capacitor regulator of a stand-alone induction generator supplying a single-phase load. International Conference on Modern Electrical and Energy Systems (MEES), 2017. doi: 10.1109/MEES.2017.8248901.

15. Benhacine T.Z.E., Nesba A., Mekhtoub S., Ibtiouen R. A balancing method for three-phase SEIG feeding a single-phase load by using switched capacitors. International Conference on Electrical Sciences and Technologies in Maghreb (CISTEM), 2018. doi: 10.1109/CISTEM.2018.8613410.

16. de Resende J.T., Schelb A.J.H.C., Ferreira R., Manasses E.P. Control of the generated voltage by a three-phase induction generator self-excited by capacitors using control techniques. IEEE International Conference on Industrial Technology, 2003. doi: 10.1109/ICIT.2003.1290386.

17. Ahmed T., Nishida K., Soushin K., Nakaoka M. Static VAR compensator-based voltage control implementation of singlephase self- excited induction generator. IEE Proceedings Generation, Transmission and Distribution, 2005, vol. 152, no. 2, pp. 145-156. doi: 10.1049/ip-gtd:20051251.

18. Shridhar L., Singh B., Jha C.S. Transient performance of the self regulated short-shunt self-excited induction generator. IEEE Transactions on Energy Conversion, 1995, vol. 10, no. 2, pp. 261-267. doi: 10.1109/60.391891.
19. Ojo O. Performance of self-excited single-phase induction generators with shunt, short-shunt and long-shunt excitation connections. IEEE Transactions on Energy Conversion, 1996, vol. 11 , no. 3 , pp. 477-482. doi: 10.1109/60.536996.

20. Fraile-Ardanuy J., Fraile-Mora J., Pedro A.G.G. Voltage control of isolated self-excited induction generator through series compensation. Przeglad Elektrotechniczny, 2012, no. 01a, pp. 132-136.

21. Abdelhamid B., Taoufik M., Lassad S. Shunt and short shunt compensation for induction machine generator. 17th International Conference on Sciences and Techniques of Automatic Control and Computer Engineering (STA), 2016. doi: 10.1109/STA.2016.7951989.

22. Jaswant S., Pawan K.Y., Abhishek K.C. Improvement in voltage profile in self excited induction generator using fuzzy logic. International Journal on Future Revolution in Computer Science \& Communication Engineering (IJFRCSCE), 2018, vol. 4 , no. 1, pp. 113-117.

23. Kasal G. Singh B. Decoupled voltage and frequency controller for isolated asynchronous generators feeding threephase four-wire loads. IEEE Transactions on Power Delivery, 2008, vol. 23, no. 2, pp. 966-973. doi: 10.1109/TPWRD.2008.915783.

24. Rajagopal V., Singh B., Kasal G. Electronic load controller with power quality improvement of isolated induction generator for small hydro power generation. IET Renewable Power Generation, 2011, vol. 5, no. 2, pp. 202-213. doi: 10.1049/ietrpg.2010.0081.

25. Silva F.B., da Silva Gonçalves F.A., Vanço W.O., de Carvalho D.P., Bissochi Jr C.A., Monteiro R.V.A., Guimarães G.C. Application of bidirectional switches in the development of a voltage regulator for self-excited induction generators. International Journal of Electrical Power \& Energy Systems, 2018, vol. 98, no. 5, pp. 419-429. doi: 10.1016/j.ijepes.2017.12.025.

26. Seyoum D., Grantham C., Rahman M.F. The dynamic characteristics of an isolated self-excited induction generator driven by a wind turbine. IEEE Transaction on Industry Applications, 2003, vol. 39, no. 4, pp. 936-944. doi: 10.1109/TIA.2003.813738.

Received 11.02.2020

Louze Lamri ${ }^{1}$, Doctor of Electrical Engineering, Professor, Abdessemad Oussama ${ }^{1}$, PhD student,

Nemmour Ahmed Lokmane ${ }^{1}$, Doctor of Electrical Engineering,

Professor,

Khezzar Abdelmalek ${ }^{1}$, Doctor of Electrical Engineering,

Professor,

${ }^{1}$ Laboratoire d'Electrotechnique de Constantine (LEC),

Mentouri Brothers University, Constantine 1,

Constantine, Algeria.

e-mail: lamri.louze@lec-umc.org,

oussama.abdessamad@lec-umc.org,

ahmed-lokmane.nemmour@lec-umc.org,

abdelmalek.khezzar@lec-umc.org

How to cite this article:

Louze L., Abdessemad O., Nemmour A.L., Khezzar A. An effective control of an isolated induction generator supplying DC load for wind power converting applications. Electrical engineering \& electromechanics, 2020, no. 3, pp. 65-69. doi: 10.20998/2074-272X.2020.3.10. 